\title{
The value of the microbiological examination in the diagnosis and monitoring of periodontitis
}

\author{
Valoarea examenului microbiologic în diagnosticul şi \\ monitorizarea parodontitei
}

\author{
Irina Lupşe', Alexandra Roman², Iulia Cristina Micu², Andrada Soanca² \\ ${ }^{1}$ Disciplina de Pedodonţie, Universitatea de Medicină şi Farmacie „Iuliu Haţieganu“, \\ Cluj Napoca, România \\ ${ }^{2}$ Disciplina de Parodontologie, Universitatea de Medicină şi Farmacie \\ „Iuliu Haţieganu“, Cluj Napoca, România
}

\begin{abstract}
The properties of subgingival niches are selective and influence the colonization of microorganisms as minority or majority members of the microbial community. Usually there is a harmonious relationship between the host and subgingival resident flora. The impairment of the subgingival homeostasis could predispose to the development of periodontitis because it allows the colonization of exogenous pathogens or the increase of the minority bacteria by exploring the new environmental opportunities. When the host could not manage the initial microbial insult, the nature of the local response to the dysbiotic subgingival biofilm provides conditions for selecting other pathogens that would amplify periodontal inflammation. As other chronic diseases, periodontitis is a polymicrobian infection in which tooth-associated biofilm plays a crucial role in the initiation and progression of the disease but it is not enough for periodontitis to develop. It is primarily the host inflammatory response that inflicts the irreversible dam-age to the periodontal tissues. A distinction between chronic and aggressive periodontitis is not possible based on the subgingival microbial fingerprint as revealed by traditional laboratory methods. Even though, mapping subgin-gival flora is an important aid in treatment planning as well as for monitoring the risk of recurrence in periodontitis patients. More advanced molecular techniques such as MALDI-TOF (matrix-assisted laser desorption ionization-time of flight) could eventually provide supplementary information that would allow the distinction between the chronic and aggressive periodontal diseases.
\end{abstract}

Keywords: maxillary sinus, implant migration, infectious complications, aspergillosis

\begin{abstract}
Proprietăţile habitatului subgingival sunt selective şi influenţează colonizarea microorganismelor sub forma unor membri majoritari sau minoritari ai comunităţii microbiene. De obicei, există o relaţie armonioasă şi stabilă între organismul gazdă şi flora rezidentă subgingivală. Ruperea acestei relaţii homeostatice permite colonizarea unor specii exogene sau creşterea proporţiei componenţilor bacterieni inţiali minoritari prin exploatarea noilor oportunităţi de mediu, ceea ce poate predispune la dezvoltarea bolii parodontale. Dacă organismul nu reuşeşte să controleze insulta microbiană iniţială, natura răspunsului la biofilmul disbiotic furnizează în continuare condiţii de selectare a unor patogeni care vor amplifica procesul inflamator parodontal. Ca şi alte boli cronice, parodontita este o infecţie polimicrobiană multifactorială în care bacteriile sunt necesare dar nu suficiente pentru declanşarea bolii şi în care marea parte a distrucţiei ţesuturilor parodontale este consecința inflamaţiei aberante declanşate la nivel parodontal de biofilmul patogen. În acest moment, nu este posibilă diferenţierea parodontitei cronice şi parodontitei agresive pe baza amprentei microbiologice subgingivale relevate de tehnicile tradiţionale de identificare. Chiar şi aşa, maparea amprentei microbiologice subgingivale este importantă pentru perfectarea planului de tratament individual şi monitorizarea pacienţilor parodontopaţi din punctul de vedere al riscului de recidivă. Este posibil ca tehnicile moleculare mai avansate, ca MALDI-TOF (matrix-assisted laser desorption ionization-time of flight), capabile să identifice nerestricţionat microbiota subgingivală, să furnizeze informaţii suplimentare celor actuale care să faciliteze distincţia dintre parodontita cronică şi cea agresivă.
\end{abstract}

REZUMAT

Cuvinte cheie: sinus maxilar, migrare implant, complicaţii infecţioase, aspergiloză 
Boala parodontală este o cauză importantă a pierderii dinților şi poate determina şi agrava diferite patologii sistemice, având un efect negativ important asupra stării generale de sănătate şi a calității vieții (1). Parodontita afectează o mare parte a populației. Astfel, studii recente comunică o prevalenţă a bolii parodontale de $47 \%$ şi valori mai mari, de $64 \%$, pentru grupul de vârstă de peste 65 de ani (2). Parodontita severă este considerată cea de-a şasea cea mai prevalentă condiție cronică, care afectează 10,8\% din populație, adică 743 milioane indivizi în întreaga lume (3). Etiologia acestei boli este una infecțioasă, dependentă de terenul gazdei, bacteriile parodontopatogene şi unii factori externi.

Suprafețele mucoase şi tegumentare ale organismului sunt larg colonizate de bacterii. Microflora orală, denumită colectiv microbiota orală şi, mai recent, microbiom oral (4), se stabileşte şi predomină pe anumite suprafețe în funcție de proprietăţile biologice şi fizice ale fiecărui loc (5) şi cuprinde bacterii, archaea, fungi, micoplasme, protozoare şi, ocazional, virusuri. Cavitatea orală găzduieşte nişe anatomice multiple cu caracteristici fizico-chimice diferite dictate de $\mathrm{pH}$, concentrația de oxigen, temperatură, potențial redox, ceea ce favorizează dezvoltarea de populații microbiene diferite, care contribuie la conturarea unei microbiote complexe (6). Microbiomul oral este unic pentru fiecare individ (7). Flora rezidentă contribuie direct sau indirect la dezvoltarea fiziologică normală a organismului, la nutriţie şi la dezvoltarea sistemului imun. Colonizatorii permanenți acționează ca o barieră față de organismele exogene sau tranzitorii, unele cu potenţial patogen. Această proprietate a biofilmului se numeşte rezistență la colonizare. Tratamentul antibiotic este un exemplu de factor care rupe această rezistență deoarece suprimă rapid flora rezidentă, ceea ce conduce la creşterea excesivă a componenților minoritari ai microflorei rezistenţi la antibiotic sau exogeni şi astfel se creează condițiile de producere a bolii (8). Astfel, flora comensală rezidentă poate fi considerată ca parte a apărării imune înnăscute. În condiții normale, microbiota orală se dezvoltă, deci, în echilibru cu organismul gazdă, cu beneficii reciproce.

Cunoştințele actuale legate de diversitatea microflorei orale au fost mult îmbogăţite de rezultatele tehnicilor de cultură, clonare şi secvenţiere a genelor. Astfel, s-au identificat aproximativ 700 de specii de bacterii la nivelul cavității orale, dintre care doar jumătate au fost cultivate (4). Aproximativ 20-30 de specii predominante au fost izolate din fiecare situs de prelevare (mucoasă sau placă dentară) $(9,10)$.

O serie de factori, cum ar fi caracteristicile genetice ale organismului gazdă, diabet, fumat, igiena orală deficitară, pot determina modificări sistemice (inflamaţie cronică şi răspuns imuno-inflamator alterat) şi perturbarea ecosistemului oral (11).

În inițierea parodontitei se produce o modificare a proporției bacteriilor subgingivale denumită disbioză, care se referă la scăderea numărului bacteriilor comensale şi creşterea proporției patogenilor parodontali (12). Răspunsul inflamator local gingival la acumularea biofilmului subgingival (13) determină modificări ale habitatului subgingival, traduse prin creşterea fluxului lichidului crevicular, sângerare şi creşterea locală a temperaturii, ceea ce diversifică disponibilitatea nutriţională şi favorizează dezvoltarea speciilor anaerobe şi a celor proteolitice (14). Acest proces proteolitic duce la creşterea uşoară a pH-ului, ceea ce favorizează dezvoltarea unor parodontopatogeni ca Porphyromonas gingivalis, Prevotella intermedia şi Fusobacterium nucleatum $(15,16)$; în plus, o alterare a expresiei genelor şi creşterea consecutivă a capacităţii proteolitice a lui $P$. gingivalis au fost raportate (15). Creşterea temperaturii subgingivale consecutive inflamației gingivale s-a asociat cu colonizarea lui Porphyromonas gingivalis, Prevotella intermedia şi Aggregatibacter actinomycetemcomitans (17). Persistenţa condițiilor disbiotice şi creşterea virulenței microbiotei subgingivale cresc riscul producerii parodontitei (18).

Biofilmul subgingival nu reprezintă doar o acumulare întâmplătoare de bacterii, ci este vorba despre un consorțiu microbian înalt organizat în funcție de o serie de afinităţi celulare şi interacțiuni metabolice dezvoltate între membrii comunității. Proximitatea celulelor una faţă de cealaltă în biofilm facilitează numeroase interacțiuni sinergice şi antagonice, formându-se adevărate rețele interconectate de celule capabile să comunice între ele (19). Proprietățile bacteriilor din biofilm diferă de cele ale celulelor planctonice, astfel că s-a observat o creştere a toleranței la agenții antimicrobieni, inclusiv la cei folosiţi în paste de dinţi şi ape de gură (20). 
O corelaţie dintre anumite asocieri bacteriene şi statusurile pardontale a fost observată (21). Astfel, s-a remarcat constanta asociere dintre parodontita cronică şi agresivă şi trei bacterii - Treponema denticola, Porphyromonas gingivalis şi Tannarella forsythia - incluse în complexul roşu şi alte nouă bacterii incluse în complexul portocaliu (22).

Porphyromonas gingivalis s-a dovedit a fi o bacterie esențială în producerea parodontitei, având capacitatea de a deregla răspunsul imun şi de a întrerupe relația homeostatică dintre biofilmul subgingival şi organism, putând orchestra inflamația parodontală prin remodelarea microbiotei normale, benigne, într-una disbiotică. Astfel, Porphyromonas gingivalis este considerat un micro-organism keystone (,keystone pathogen“), care susţine şi stabilizează microbiota asociată parodontitei (23). Acest concept, cunoscut ca keystone pathogen hypothesis, consideră capacitatea patogenilor keystone de a stimula inflamația chiar dacă sunt componenți minori cantitativ ai microbiotei, ceea ce contrastează cu inflamația indusă de patogenii dominanți ai microbiotei, care cauzează şi supresia simultană a comensalilor (24). Porphyromonas gingivalis mai degrabă a dezvoltat strategii complexe ca să evite componenți ai sistemului imun decât să acționeze direct, ca o bacterie pro-in-flamatorie. Astfel, Porphyromonas gingivalis slăbeşte imunitatea înnăscută, astfel că permite creşterea şi devoltarea biofilmului în ansamblu, declanşând o modificare destructivă în relația homeostatică normală bacterii-organism (23). Alterarea numărului comunității comensale, asociată co-lonizării lui Porphyromonas gingivalis, precede instalarea pierderii de os de natură inflamatorie. Porphyromonas gingivalis nu poate cauza singur parodontită, în absența comunității comensale (25). Aceste alterări se produc imediat după colonizarea lui Porphyromonas gingivalis. Mai mult decât atât, prezența lui Porphyromonas gingivalis într-o comunitate multibacteriană normală alterează modelul expresiei genice de la nivelul comunității (23).

Creşterea necontrolată a bacteriilor subgingivale creşte componenta inflamatorie distructivă, ceea ce generează produşi de degradare şi furnizează elemente nutritive care modifică în continuare biofilmul şi stabilizează tranziția spre o microbiotă care provoacă boală.

Eradicarea completă a florei subgingivale disbiotice nu este posibilă, iar eliminarea neselectivă prin tratament poate favoriza colonizarea patogenilor şi ocuparea unei poziţii dominante în comunitate în defavoarea bacteriilor comensale. Dezvoltarea de strategii terapeutice care să țintească patogenii cheie ca Porphyromonas gingivalis pare o idee de perspectivă (26).

Diagnosticul afecțiunilor parodontale este esențial pentru evoluția modificărilor parodontale şi statusul dentiției, cu atât mai mult pentru parodontitele agresive pentru care au fost raportate pierderi tisulare rapide şi dificultăţi de control asupra bolii. Pentru un diagnostic pozitiv şi diferențiat al bolii parodontale este nevoie de disponibilitatea datelor anamnestice şi maparea clinică şi radiografică a statusului structurilor parodontale. Diagnosticul este şi un punct de plecare pentru elaborarea planului de tratament (27). Unul dintre scopurile majore ale tratamentului parodontal este de rezolvare a inflamaţiei şi reducere a infecției. Majoritatea formelor de îmbolnăvire, chiar şi parodontitele agresive, sunt tratabile, dar acest lucru implică o complianță exemplară a pacientului şi elaborarea unui diagnostic complet care să surprindă o serie de variabile etiologice individuale. Unele forme de parodontită, mai ales cele agresive, răspund mai puțin previzibil la terapia inițială convențională (28), de multe ori din cauza inabilității practicianului de a adresa etiologic terapia efectuată.

Parodontitele agresive, dar şi unele parodontite cronice, sunt asociate cu o infecție cu anumiţi parodontopatogeni parodontali extrem de virulenţi ca $A$. actinomycetemcomytans sau Porphyromans gingivalis (29). Instrumentarea mecanică subgingivală reduce numărul total de bacterii subgingivale şi proporția unor bacterii Gram-negative, dar pentru nicio pungă parodontală infectată inițial cu $A$. actinomycetemcomytans nu s-a obținut eradicarea bacteriei (30). Terapia adjuvantă antibiotică poate îmbunătăți efectele instrumentării mecanice când $A$. actinomycetemcomytans este prezent (31). Pe de altă parte, deşi A. actinomycetemcomytans este mai prevalent la pacienții cu parodontită agresivă, bacteria nu este identificată la toți pacienții cu acest diagnostic (32) şi deci o terapie antibiotică adjuvantă în aceste situații poate fi considerată un supratratament. De asemenea, se pare că, în parodontitele agresive pozitive pentru Porphyromonas gingivalis şi Tannerella forsythia, terapia antibiotică adjuvantă nu oferă îmbunătățiri clinice suplimentare (33). 
O metaanaliză recentă a arătat că terapia mecanică non-chirurgicală asociată cu antibioterapie, în parodontite, a determinat, după 6 luni post-operator, o reducere semnificativă cu $32 \%$ a persoanelor pozitive pentru Porphyromonas gingivalis şi cu $25 \%$ a celor pozitive pentru $A$. actinomycetemcomytans, în comparaţie cu grupurile control (tratate doar prin terapie nonchirurgicală) (34). După un an, efectul s-a menținut pentru Porphyromonas gingivalis, dar diferențele nu au mai fost semnificative pentru A. actinomycetemcomytans, posibil din cauza numărului mai redus de date disponibile pentru acest moment de evaluare. De asemenea, s-a mai observat că, dacă în analiza statistică a fost considerată doar terapia non-chirurgicală convențională (multiple sesiuni de instrumentare), diferența dintre grupurile de tratament cu privire la detecția lui $A$. actinomycetemcomytans a fost nesemnificativă. Dacă analiza a evaluat protocolul full-mouth desinfection, diferența a devenit semnificativă. Aceste aspecte subliniază că, în cazul unei infecții subgingivale cu $A$. actinomycetemcomytans şi când se prevede o terapie antibiotică sistemică, instrumentarea mecanică subgingivală trebuie realizată în cât mai scurt timp posibil conform unui protocol full-mouth desinfection (34).

Porphyromonas gingivalis poate servi ca un marker surogat al disbiozei comunităţii bacteriene subgingivale (23). De asemenea, ca patogen important asociat parodontitei agresive, A. Actinomycetemcomytans poate juca un rol important în sinergia polimicrobiană care inițiază boala (35).

Din aceste perspective, analiza microbiologică poate fi o unealtă utilă pentru perfectarea planului de tratament în parodontite, în funcție de make-upul microbiologic subgingival şi pentru monitorizarea riscului de recidivă a bolii, mai ales în contextul planificării unor terapii implantare sau protetice de reabilitare.

Metodele bazate pe identificarea acizilor nucleici ca FISH (in situ hybridization) şi strategiile bazate pe PCR (Polymerase Chain Reaction) au scăzut dramatic timpul de obținere a rezultatului microbiologic şi au adus îmbunătăţiri importante atât fluxului de lucru din laboratoare, cât şi prognosticului pacienților (36). Metodele nu necesită viabilitatea bacteriilor şi elimină etapa de cultură. Secvențierea genetică este o altă opțiune atractivă pentru identificarea universală a fungilor şi bacteri- ilor. Secvențierea genetică 16S rRNA şi 18S rRNA (pentru identificarea de bacterii şi respectiv de fungi) este o metodă diagnostică puternică cu o capacitatea discriminatorie importantă pentru determinările la nivel de specie sau subspecie (37). Porțiunea genelor $16 \mathrm{~S}$ rRNA este o parte genetică stabilă a ADN-ului bacterian (dar nu numai) folosită astăzi pentru taxonomia bacteriană (38). Gradul de conservare derivă din importanţa 16S rRNA ca fiind component critic al funcției celulei bacteriene (38). Gena este suficient de mare, cu un polimorfism suficient pentru a furniza măsurători distincte şi statistic valide. De obicei, primerii comerciali sunt complementari regiunilor conservate ale $16 \mathrm{~S}$ rRNA de la începutul genei şi din regiunea 540-bp sau de la sfârşitul întregii secvenţe (aproximativ regiunea 1550-bp). Deşi lungimile de 500 şi $1500 \mathrm{bp}$ sunt cele mai folosite pentru secvenţiere şi comparare, secvențele pot avea diferite lungimi. Secvenţierea genei $16 \mathrm{~S}$ rRNA a fost determinată pentru multe suşe. Cea mai mare bază de date de secvențe nucleotidice, Gen Bank, are depozitate peste 200 de milioane de secvențe (38). Metodele de secvențiere genetică sunt folosite în principal de laboratoarele clinice complexe şi cele de referinţă pentru testarea de confirmare şi reflexă (teste importante realizate automat, fără comandă specifică din partea medicului, atunci când rezultatele testelor inițiale au atins criteriile de predeterminare, nefiind necesare alte prelevări de produs biologic şi pentru care testele preliminare au determinat rezultate neconcludente). Secvențierea genetică rRNA necesită instrumente speciale şi spații dedicate, ceea ce o face metodă nepractică pentru unele laboratoare. Astfel, folosirea instrumentelor automatizate pentru analiza fenotipică a izolatelor bacteriene (culturi pure) încă predomină pentru identificarea microbiologică de rutină (39).

Una dintre limitările majore asociate acestor metode este că majoritatea acestor investigații necesită cunoaşterea avansată a caracteristicilor microorganismului sau a probabilităţii ca acel microroganism să fie prezent, pentru a putea selecta evaluarea corectă care să corespundă aplicației de testare. În plus, pentru infecțiile polimicrobiene, pentru caracterizarea completă a probei clinice sunt necesare multiple evaluări moleculare, cultura prealabilă şi separarea sau testarea adiţională downstream; acest lucru creşte costul şi timpul de inves- 
tigare. Astfel, maparea microbiologică a situsurilor subgingivale nu este posibilă prin tehnicile curente, aspect care nu trebuie neglijat având în vedere diversitatea florei orale (40) şi posibilitatea ca speciile implicate în etiologia parodontitelor să fie mai complexe decât cele descrise până în acest moment. Alte neajunsuri asociate metodelor moleculare se referă la imperfecțiunile de acuratețe, robustețe şi timpi mari de identificare (39).

Aceste aspecte ar putea fi remediate de noile metode alternative spectrofotometrice de identificare rapidă şi universală care au fost dezvoltate şi validate. MALDI-TOF (matrix-assisted laser desorption ionization-time of flight) poate răspunde neajunsurilor metodelor moleculare. Metodele spectrofotometrice sunt la începutul dezvoltării lor şi au fost restrânse iniţial la laboratoarele de cercetare fundamentală şi folosite pentru identificarea microbiologică a compoziţiei celulei bacteriene şi taxonomică. Avantajele spectrometriei de masă se referă la tehnologia robustă, puterea mare de analiză şi sensibilitatea analitică mare. Dintre dezavantajele spectrometriei de masă face parte costul ridicat, ceea ce determină o utilizare actuală restrictivă doar la marile laboratoare de referință, dar o reducere a prețurilor ar putea facilita folosirea ei de rutină chiar în laboratoarele mici. Adresarea altor dezavantaje ar putea conduce la modificări care să permită analiza unei palete mai largi de microbi şi molecule, standardizări care să faciliteze folosirea de către o forță de muncă neuniformă şi integrarea în sistemele informatice ale laboratoarelor. Astfel, metodele de spectrometrie de masă ar putea deveni o unealtă completă pentru majoritatea laboratoarelor de diagnostic microbiologic (39).

Folosirea spectrometriei de masă pentru identificarea bacteriană (41) a fost urmată de dezvoltarea MALDI (matrix-assisted laser desorption ionization). Metoda MALDI a fost introdusă prima dată în 1987, susţinută de alte experimente (42) şi onorată cu premiul Nobel în 2002. De atunci, MALDI-TOF MS (matrix-assisted laser desorption ionizationtime of flight mass spectrometry) a evoluat într-o metodă analitică rapidă şi fiabilă de caracterizare a colecțiilor microbiene din laboratoarele clinice.

Tehnologia MALDI-TOF MS cuprinde o componentă de ionizare a probei de analizat (colonie microbiană, material de cultură sanguină, extracte proteice) şi a matricii cu care proba se amestecă.
Astfel, peste proba clinică se adaugă o soluție saturată a unui compus organic cu masă moleculară mică denumit matrice. Ionizarea proteinelor este esențială pentru identificarea microbiană, deoarece permite identificarea de biomolecule mari, inclusiv proteine ribozomale, de până la 100 kDa $(42,39)$. Odată ionizate, proteinele din proba clinică sunt analizate de o componentă a spectrometrului de masă denumită analizor de masă (de exemplu TOF), astfel încât furnizează informații caracteristice despre compoziția probei. MALDI foloseşte o sursă de ionizare pulsatilă, în timp ce un plus de ioni din proba clinică este produs odată cu expunerea instantanee la conul laser. Natura pulsatilă a procesului MALDI se potriveşte în mod natural cu analizorul de masă TOF (Time of Flight Analyzer) care necesită ca toți ionii să intre simultan în tubul (flight) de conducere (43). În plus, analizorul de masă TOF este ideal pentru MALDI datorită limitei de masă virtual nelimitată în contextul în care MALDI produce tipic ioni cu raport masă/încărcare mare. De obicei, pentru asigurarea standardizării şi reproductibilității, analizoarele de masă sunt optimizate şi vândute ca parte a pachetului de instrumente dedicat identificării de microorganisme.

Analizorul TOF funcționează după principiul conform căruia aplicarea unui câmp electrostatic $(\mathrm{eV})$ unui material ionizat generează ioni cu anumită sarcină (z) care pot fi accelerați, împărțind cu ei energia cinetică (KE). Metoda TOF lineară are o sensibilitate şi viteză mare, fiind capabilă să analizeze molecule în concentrație fentomolară $\left(10^{-15}\right.$ moli/litru) şi atomolară ( $\left.10^{-18} \mathrm{moli} / \mathrm{litru}\right)$ (44). Una dintre limitările metodei TOF este că are o rezoluție mică din cauza peak-ului larg ce se poate produce datorită distribuției spaţiale a energiilor din pulsul laser, ceea ce determină ioni cu aceeaşi $\mathrm{m} / \mathrm{z}$, având însă energii cinetice diferite. Atunci când se folosesc platformele MALDI-TOF MS pentru analiza de probe clinice, TOF linear este cel mai des folosit.

Multe studii timpurii care au folosit această metodă au constatat că spectrele generate de microorganisme prezintă variații mari în funcție de condițiile de cultură şi de laboratoarele de analiză (45). Bazele de date inițiale folosite pentru identificarea şi caracterizarea microbiană prin MALDI-TOF MS erau dezvoltate ,in house“ pentru a răspunde nevoilor interne ale laboratorului şi conțineau multe or- 
ganisme din colecțiile de suşe ale investigatorilor individuali, făcând dificile comparațiile între studii. Deşi bazele de date ,,in house“ sunt încă utilizate, analizele de rutină folosesc astăzi baze de date comercializate cu sistemele MALDI-TOF MS. Din cauza primelor rezultate contradictorii s-a pus problema standardizării condițiilor de cultură, a condițiilor MS şi a procesării preanalitice (folosirea de colonii bacteriene) pentru stabilizarea şi robustețea spectrelor generate şi îmbunătăţirea acurateței şi fiabilității MALDI-TOF MS pentru identificarea bacteriană.

Ca şi alte boli cronice, parodontita este o infecție polimicrobiană (46) multifactorială în care bacteriile sunt necesare dar nu suficiente pentru declanşarea bolii (47). Parodontita este iniţiată de componentele biofilmului subgingival, dar cea mai mare parte a distrucției țesuturilor parodontale este consecința inflamației aberante declanşate la nivel

\section{BIBLIOGRAFIE}

1. Gully N., Bright R., Marino V., Marchant C., Cantley M., Haynes D., Butler C., Dashper S., Reynolds E., Bartold M. Porphyromonas gingivalis peptidyl-arginine deiminase, a key contributor in the pathogenesis of experimental periodontal disease and experimental arthritis, PLoS One 2014; (6):e100838

2. Eke P.I., Dye B.A., Wei L., Thornton-Evans GO, Genco R.J. CDC Periodontal Disease Surveillance workgroup. Prevalence of periodontitis in adults in the United States: 2009 and 2010. J Dent Res. 2012; 91(10):914-20

3. Frencken J.E., Sharma P., Stenhouse L., Green D., Laverty D., Dietrich T. Global epidemiology of dental caries and severe periodontitis - a comprehensive review. J ClinPeriodontol. 2017:S94-S105

4. Dewhirst F.E., Chen T., J. Izard, B.J. Paster, A.C. Tanner, Yu W.H., Lakshmanan A., Wade W.G. The human oral microbiome, J.Bacteriol. 2010; 192:5002-5017

5. Samaranayake L., Matsubara V.H. Normal Oral Flora and the Oral Ecosystem. Dent Clin N Am 2017; 61:199-215

6. Simon-Soro A., Tomas I., Cabrera-Rubio R., Catalan M.D., Nyvad B., Mira A. Microbial geography of the oral cavity. J Dent Res 2013 ; 92(7):616-21

7. Ding T., Schloss P.D. Dynamics and associations of microbial community types across the human body. Nature 2014; 509(7500):357-60.

8. Topoll H.H., Lange D.E., Muller R.F. Multiple periodontal abscesses after systemic antibiotic therapy. J ClinPeriodontol 1990; 17(4):268-72.

9. Aas J.A., Paster B.J., Stoked L.N., Olsen I., Dewhirst F.E. Defining the normal bacteria flora of the oral cavity. J ClinMicrobiol 2005: 43: 5721-5732

10. Keijser B.J., Zaura E., Huse S.M., van der Vossen J.M., Schuren F.H., Montijn R.C., Ten Cate J.M., Crielaard W. Pyrosequencing analysis of the oral microflora of healthy adults. J.Dent Res 2008:87:1016-1020 parodontal de biofilmul patogen (48). În acest moment, nu este posibilă diferențierea parodontitei cronice şi parodontitei agresive pe baza amprentei microbiologice subgingivale relevate de tehnicile tradiționale de identificare (49). Este posibil ca tehnicile moleculare mai avansate capabile să identifice nerestricționat microbiota subgingivală să furnizeze informații suplimentare celor actuale care să faciliteze distincția dintre formele clinice de boală. În plus, maparea amprentei microbiologice subgingivale este importantă pentru perfectarea planului de tratament individual şi monitorizarea pacienţilor din punctul de vedere al riscului de recidivă.

Mulțumiri. Această lucrare a fost realizată în cadrul Proiectului de Cercetare Doctorală susținut de Universitatea de Medicină şi Farmacie „Iuliu Hațieganu“, Cluj Napoca, Nr. contract 1300/40 din 13.01.2017.

Conflict of interest: none declared Financial support: none declared

11. Stone V.N., Xu P. Targeted antimicrobial therapy in the microbiome era. Mol Oral Microbiol. 2017: 10.1111/ omi.12190.

12. Berezow A.B., Darveau R.P. Microbial shift and periodontitis. Periodontol 2000. 2011; 55(1):36-47

13. Loe H., Thielade E., Jensen S.B. Experimental gingivitis in man. J Periodontol 1965:36:177-187

14. TerSteeg P.F., Van der Hoeven J.S., De Jong M.H., Van Munster P.J.J., Jansen M.J.H. Enrichment of subgingival microflora on human serum leading to accumulation of Bacteroides species, peptostreptococci and fusobacteria. Antonie Van Leeuvenhoek 1987:53:261-272.

15. McDermid A.S., McKee A.S., Marsh P.D. Effect of environmental $\mathrm{pH}$ on enzyme activity and growth of Bacteroides gingivalis W50. Infect Immun 1988:56:1096-1100

16. Rogers A.H., Zilm P.S., Gully N.J., Pfenning A.L., Marsh P.D. Aspects of the growth and metabolism of Fusobacteriumnucleatum ATCC 10953 in continuous culture. Oral Microbiollmmunol 1991:6:250-255

17. Haffajee A.D., Socransky S.S., Smith C., Dibart S., Goodson J.M. Subgingival temperature (III). Relation to microbial counts. J ClinPeriodontol. 1992;19(6):417-22

18. Marsh P.D. Are dental diseases examples of ecological catastrophes? Microbiology 2003:149:279-294.

19. Kuramitsu H.K., He X., Lux R., Anderson M.H., Shi W. Interspecies interactions within oral microbial communities. MicrobiolMolBiol Rev 2007:71:653-670)

20. Pratten J., Wilson M. Antimicrobial susceptibility and composition of microcosm dental plaques supplemented with sucrose. Antimicrob Agents Chemother 1999:43:1595-1599

21. Socransky S., Haffajee A.D., Cugini M.A., Smith C., Kent R.L. Jr., Microbial complexes in subgingival plaque, J.Clin. Periodontol. 1998; 25:134-144

22. Rescala B., Rosalem W.Jr., Teles R.P., Fischer R.G., Haffajee A.D., Socransky S.S., Gustafsson A., Figueredo 
C.M. Immunologic and microbiologic profiles of chronic and aggressive periodontitis subjects. J Periodontol. 2010; 81(9):1308-16

23. Hajishengallis G., Darveau R.P., Curtis M.A. The keystonepathogen hypothesis. Nat Rev Microbiol. 2012 Oct; 10(10):717-25

24. Stecher B. et al. Salmonella entericaserovartyphimurium exploits inflammation to compete with the intestinal microbiota. PLoS Biol. 2007; 5:2177-89.

25. Hajishengallis G., Liang S., Payne M.A., Hashim A., Jotwani R., Eskan M.A., McIntosh M.L., Alsam A., Kirkwood K.L., Lambris J.D., Darveau R.P., Curtis M.A. Low-abundance biofilm species orchestrates inflammatory periodontal disease through the commensal microbiota and complement. Cell Host Microbe. 2011; 10:497-506.

26. Stone V.N., Xu P. Targeted antimicrobial therapy in the microbiome era. Mol Oral Microbiol. 2017: 10.1111/ omi.12190.

27. Teughels W., Dhondt R., Dekeyser C., Quirynen M. Treatment of aggressive periodontitis. Periodontol 2000. 2014 Jun; 65(1):107-33

28. Herrera D., Sanz M., Jepsen S., Needleman I., Roldán S. A systematic review on the effect of systemic antimicrobials as an adjunct to scaling and root planing in periodontitis patients. J ClinPeriodontol. 2002;29 Suppl 3:136-59

29. Könönen E., Müller H.P. Microbiology of aggressive periodontitis. Periodontol 2000, 2014; 65(1):46-78.

30. Slots J., Rosling B.G. Suppression of the periodontopathic microflora in localized juvenile periodontitis by systemic tetracycline. J ClinPeriodontol. 1983:10(5):465-86

31. Van Winkelhoff A.J., Tijhof C.J., de Graaff J. Microbiological and clinical results of metronidazole plus amoxicillin therapy in Actinobacillus actinomycetemcomitansassociated periodontitis. J Periodontol. 1992:63(1):52-7

32. Tonetti M.S., Mombelli A. Early-onset periodontitis. Ann Periodontol. $1999 ; 4(1): 39-53$

33. Guerrero A., Nibali L., Lambertenghi R., Ready D., Suvan J., Griffiths G.S., Wilson M., Tonetti M.S. Impact of baseline microbiological status on clinical outcomes in generalized aggressive periodontitis patients treated with or without adjunctive amoxicillin and metronidazole: an exploratory analysis from a randomized controlled clinical trial. J ClinPeriodontol. 2014;41(11):1080-9.

34. Dakic A., Boillot A., Colliot C., Carra M.C., Czernichow S., Bouchard P. Detection of Porphyromonasgingivalis and Aggregatibacteractinomycetemcomitans after Systemic Administration of Amoxicillin Plus Metronidazole as an Adjunct to Non-surgical Periodontal Therapy: A Systematic Review and Meta-Analysis. Front Microbiol. 2016;7:1277

35. Nibali L. Aggressive Periodontitis: microbes and host response, who to blame? Virulence. 2015;6(3):223-8

36. Forrest G.N., Roghmann M.C., Toombs L.S., Johnson J.K., Weekes E., Lincalis D.P., Venezia R.A. Peptide nucleic acid fluorescent in situ hybridization for hospital-acquired enterococcal bacteremia: delivering earlier effective antimicrobial therapy. Antimicrob. Agents Chemother. 2008; 52:3558-3563

37. Woo P.C.Y., Lau S.K.P., Teng J.L.L., Tse H., Yuen K.Y. Then and now: use of $16 \mathrm{~S}$ rDNA gene sequencing for bacterial identification and discovery of novel bacteria in clinical microbiology laboratories. Clin. Microbiol. Infect. 2008; 14:908-934.

38. Clarridge J.E. 3rd. Impact of $16 \mathrm{~S}$ rRNA gene sequence analysis for identification of bacteria on clinical microbiology and infectious diseases. ClinMicrobiol Rev. 2004; 17(4):840-6

39. Clark A.E., Kaleta E.J., Arora A., Wolk D.M. Matrix-assisted laser desorption ionization-time of flight mass spectrometry: a fundamental shift in the routine practice of clinical microbiology. ClinMicrobiol Rev. 2013 Jul; 26(3):547-603

40. Paster B.J., Dewhirst F.E. Molecular microbial diagnosis. Periodontol 2000. 2009; 51:38-44

41. Anhalt J.P., Fenselau C. Identification of bacteria using mass spectrometry. Anal. Chem. 47:219-225

42. Karas M., Bachmann D., Bahr U., Hillenkamp F. Matrixassisted ultraviolet laser desorption of non-volatile compounds. Int. J. Mass Spectrom. Ion Process. 1975:78:53-68

43. Cotter R.J. Laser mass spectrometry: an overview of techniques, instruments and applications. Anal. Chim. Acta 1987; 195:45-59

44. Onnerfjord P., Nilsson J., Wallman L., Laurell T., MarkoVarga G. Picoliter sample preparation in MALDI-TOF MS using a micromachined silicon flow-through dispenser. Anal. Chem. 1998; 70:4755-4760

45. Wunschel S.C., Jarman K.H., Petersen C.E., Valentine N.B., Wahl K.L., Schauki D., Jackman J., Nelson C.P., White E. Bacterial analysis by MALDI-TOF mass spectrometry: an inter-laboratory comparison. J. Am. Soc. Mass Spectrom. 2005; 16:456-462

46. Peters B.M., Jabra-Rizk O.M., May O., Costerton J.W., Shirtliff M.E. Polymicrobial interactions: impact on pathogenesis and human diseases, Clin. Microbiol. Rev. 2012; 25:193-213.

47. Socransky S.S., Haffajee A.D. The bacterial etiology of destructive periodontal disease:currentconcepts. J Periodontol, 1992:63(Suppl 4):322-331

48. Van Dyke T.E. The management of inflammation in periodontal disease. J Periodontol, 2008:79(Suppl 8):16011608

49. Van der Velden U. What exactly distinguishes aggressive from chronic periodontitis: is it mainly a difference in the degree of bacterial invasiveness? Periodontol 2000. 2017; 75(1):24-44 